\title{
Penyelesaian Konflik Berbasis Desa di Indonesia (Studi Kasus di Desa Yosorejo, Jawa Tengah)
}

\author{
M. Ya'kub Aiyub Kadir* \\ DOI: https://doi.org/10.22304/pjih.v4n1.a9
}

\begin{abstract}
Abstrak
Penyelesaian konflik berbasis desa harus menjadi acuan dalam pengembangan hukum di Indonesia yang semakin formalistik dan jauh dari rasa keadilan masyarakat. Hal ini disebabkan karena pengaruh penerapan sistem hukum warisan Belanda yang masih mendominasi. Tulisan ini menggunakan metode penelitian empiris dengan mengumpulkan data melalui studi lapangan di Desa Yosorejo, Jawa Tengah, sebagai fakta yang kemudian menjadi argumen untuk mengkritisi lajunya formalisasi hukum di Indonesia di tengah derasnya infilterasi budaya asing dan perkembangan teknologi informasi. Keberhasilan masyarakat Desa Yosorejo dalam meredam dan meminimalisasi konflik diharapkan dapat menjadi acuan bagi pemerintah Indonesia untuk menganalisa kembali sistem hukum yang didasarkan kepada kearifan lokal sebagai hukum yang hidup dalam proses penyelesaian konflik.
\end{abstract}

Kata kunci: desa Yosorejo, hukum formal, kearifan lokal, pengembangan hukum, penyelesaian konflik.

\section{Village-based Conflict Settlement in Indonesia (A Study in Village Yosorejo, Middle Java)}

\begin{abstract}
Amidst the rigid and formal legal development, the local wisdom-based conflict settlement could be the alternative basis to farther the legal development in Indonesia. The rigid legal development is due to the overwhelmingly domination from the remnant of colonial Dutch legal system still inherited until today. This paper used empirical methodology through field study in Yosorejo Village, Middle Java Province. This paper will use the field study data as statement of fact as argument that the ongoing culture infiltration from foreigners and the massive technology development might adversely impact the existing situation of legal development in Indonesia. Therefore, the success of local people of Yosorejo Village to minimize conflict might become a turning point for the Indonesian government to take into account the development of local wisdom as a living law in conflict settlement processes in its current legal development.
\end{abstract}

Keywords: Yosorejo village, formal law, local wisdom, legal development, conflict settlement.

PADJADJARAN Jurnal IImu Hukum Volume 4 Nomor 1 Tahun 2017 [ISSN 2460-1543] [e-ISSN 2442-9325]

* Dosen Fakultas Hukum Unsyiah, Jl. Putro Phang No. 1, Kopelma Darussalam, Banda Aceh, m.yakub.akadir@unsyiah.ac.id, S.Ag. (IAIN Ar-Raniry, Banda Aceh), LL.M. (Oxford Brookes University, United Kingdom) 


\section{A. Pendahuluan}

Secara geografis, Desa Yosorejo terletak di Kecamatan Petungkriyono, Kabupaten Pekalongan, Provinsi Jawa Tengah. Persisnya $43 \mathrm{~km}$ arah selatan Kabupaten Pekalongan, dengan ketinggian $1300 \mathrm{~m}$ di atas permukaan laut, luas wilayahnya mencapai 7.358,523 Ha. Batas wilayah sebelah utara adalah Kecamatan Doro dan Talun, sebelah selatan dengan Kecamatan Wanayasa Kabupaten Banjar Negara, sebelah timur dengan Kecamatan Bandar Kabupaten Batang, dan sebelah barat dengan Kecamatan Lebakbarang. ${ }^{1}$ Dengan kondisi yang jauh dari pusat kota di Provinsi Jawa Tengah, Semarang, Kecamatan Petungkriyono tergolong terisolir dari berbagai akses kehidupan kota, seperti akses transportasi, pendidikan, ekonomi, dan politik.

Kehidupan pedesaan yang santun dengan adat Jawa yang kental dan kondisi alam pegunungan yang berhawa dingin memberikan kehidupan yang nyaman dan sejuk. Hanya sekitar 1 atau 2 jam di pagi hari disinari matahari, kemudian kabut mulai merebak menutupi pandangan. Hal ini menjadikan daerah ini menarik dalam konteks dinamika perilaku masyarakat dalam memahami dan menyelesaikan perselisihan secara sederhana di tengah dominasi sistem hukum formal yang legistik. Nilai-nilai kebersamaan dan kebijaksanaan yang terlihat dari berbagai upaya yang dilakukan untuk meminimalisasi atau menghindari konflik-konflik tersebut pantas untuk diapresiasi. Nilai-nilai ini tertanam secara turun-temurun secara lisan dari satu generasi ke generasi yang lain.

Tingkat pendidikan yang rata-rata lulusan Sekolah Dasar (SD), dan sebagian kecil Sekolah Menengah Pertama (SMP), sedangkan Sekolah Menengah Atas (SMA) baru dibangun dalam 2 tahun terakhir, sehingga belum ada lulusan satupun. Demikian juga dengan universitas, yang hanya terdapat di kota Pekalongan, sekitar $40 \mathrm{~km}$ dari kota kecamatan Mudal. Tidak ada transportasi tetap kecuali doplak ${ }^{2}$ yang berfungsi hanya untuk membawa hasil kebun dan sapi ke kota pada hari dan jam tertentu. ${ }^{3}$ Namun demikian, hal ini tidak menyebabkan masyarakat desa menjadi tidak beraturan dan berkonflik.

Nilai-nilai kearifan lokal masih sangat kental terlihat, seperti bagaimana setiap kali mengunjungi rumah masyarakat desa, akan selalu disuguhi air teh atau kopi serta kue, bahkan pada saat waktu makan, akan langsung dipersiapkan makanan. Selain itu tidak nampak ada rasa kecurigaan kepada para pendatang, yang menandakan kehidupan yang masih sederhana dan alami tanpa ada prasangka dan ketakutan kepada pihak pendatang luar. Namun sayangnya, pemerintah terlihat

$1 \quad$ Lihat secara lengkap di Badan Perencanaan Pembangunan Daerah (Bappeda) dan Badan Pusat Statistik (BPS) Pekalongan, Kecamatan Petungkriyono dalam Angka 2008, Bappeda dan BPS Pekalongan, Juni 2009, hlm. 1.

2 Doplak adalah sejenis mobil pick up L- 300 yang menjadi transportasi publik utama masyarakat di Petungkriyono. Doplak selain mengangkut hasil pertanian dan peternakan, juga manusia.

3 Jadwal doplak pada umumnya adalah di pagi hari yaitu pukul 4 pagi dan di sore hari pada pukul 3 sore. 
kurang memperhatikan kondisi fasilitas pendidikan di daerah ini. Bahkan ada sebuah SD di Desa Wonodadi yang muridnya hanya berjumlah 12 orang dan gurunya seringkali tidak hadir. ${ }^{4}$

Teknologi sederhana seperti televisi sudah mulai masuk ke daerah ini sekitar sepuluh tahun yang lalu, dengan memakai baterai dan sumber daya listrik air. Hal ini membuat masyarakat mengenal pola-pola kehidupan kota. Pengaruh kehidupan kota lambat laun semakin terasa, seperti para remaja sudah ada yang bergaya rambut punk, memiliki telepon genggam, dan mendengarkan musik-musik kota. Bagi sebagian warga, menonton berita juga hal yang lumrah, sehingga mereka tetap mengetahui informasi terkini tentang kondisi bangsa dan negara di luar mereka. Namun demikian, beberapa tradisi dalam rangka penghormatan terhadap alam masih dilakukan.

Alam menjadi pemberi inspirasi utama dalam kehidupan masyarakat desa. Alam mengajari mereka bagaimana mempertahankan hidup dan bersikap. Masyarakat seperti ini dapat digolongkan sebagai masyarakat bersahaja/sederhana yang digunakan oleh Soerjono Soekanto: “Masyarakat bersahaja tidak mempunyai pengadilan maupun konsepsi mengenai negara". ${ }^{5}$ Lebih lanjut beliau menjelaskan “...kekuatan yang mengikat yang didasarkan pada ketergantungan yang terwujud dalam hubungan timbal balik yang terwujud dalam proses saling menukar jasa dalam bentuk upacara-upacara, adanya pengawasan umum menambah kekuatan mengikat dari aturan-aturan hukum tersebut". ${ }^{6}$ Hal ini semakin menarik jika kita dapat melihat perbedaan corak perilaku hukum dalam masyarakat berbeda di Indonesia dan menemukan benang merah di mana perdamaian, kerukunan, dan kondisi alam akan memberikan warna hukum tertentu. Meskipun situasi Yosorejo, Petungkriyono yang marginal tapi mereka sudah berbudaya madani". ${ }^{7}$

Berdasarkan latar belakang di atas, maka tulisan ini hendak mengungkapkan dua persoalan, Pertama, mengenai apa saja konflik-konflik yang terjadi dan bagaimanakah penyelesaiannya dalam perspektif masyarakat sederhana di Desa Yosorejo, dan kedua, faktor-faktor apa yang menyebabkan pola penyelesaian konflik dalam masyarakat sederhana di Desa Yosorejo dapat bertahan di tengah hegemoni penyelesaian sengketa litigasi formal di Indonesia. Penulis berharap penyelesaian sengketa berbasis desa ini dapat menjadi acuan dalam pembangunan hukum di Indonesia sekarang ini.

4 Informasi dari Sehat Ihsan Shadiqin yang menjadi guru pengganti pada saat gurunya tidak hadir pada tanggal 19 Januari 2010.

5 Soerjono Soekanto, Antropologi Hukum, Materi Pengembangan Ilmu Hukum Adat, Jakarta: CV. Rajawali, 1998, hlm. 11.

6 Baca selengkapnya di Soerjono Soekanto, Ibid., hlm. 1.

7 Wawancara dengan Bapak Kepala Kantor Urusan Agama Petungkriyono pada hari Kamis, 21 Januari 2010. 


\section{B. Metode Penelitian}

Penelitian ini dilakukan di Desa Yosoreja, dan beberapa desa lainnya di Kecamatan Petungkriyono, Kabupaten Pekalongan, Jawa Tengah. Desa-desa ini diambil karena letak geografisnya yang jauh dari kota besar dan masyarakatnya yang masih tergolong sederhana. Penelitian ini dilakukan dengan pedekatan empiris, dengan mendeskripsikan perilaku masyarakat desa dalam hubungannya dengan sebuah sistem hukum penyelesaian sengketa, yang merupakan salah satu metode penelitian dalam antropologi hukum. ${ }^{8}$ Dalam pengumpulan data, penelitian ini menggunakan dua teknik, yaitu studi lapangan untuk menghimpun data primer dan studi pustaka untuk menghimpun data sekunder. Studi lapangan dilakukan dengan teknik wawancara langsung (semi-struktur) dan tidak langsung (alamiah) serta merasakan langsung kondisi di lapangan dengan tinggal bersama masyarakat Desa Yosoreja selama 2 minggu. Diskusi dan wawancara langsung dilakukan dengan beberapa stakeholder seperti Ketua Rukun Warga (RW), Ketua Rukun Tetangga (RT), Kepala Desa, Kepala Kantor Urusan Agama Petungkriyono, Staf Kantor Camat Petungkriyono, Ketua Pengadilan Negeri Petungkriyono, Ketua Pengadilan Agama Pekalongan, polisi di Kepolisian Sektor (Polsek) Petungkriyono, dan masyarakat secara umum. Selanjutnya data yang diperoleh dikelompokkan sesuai dengan isinya dan dianalisa secara kualitatif, untuk kemudian disusun secara sistematis sesuai dengan perumusan masalah di atas.

\section{Hasil Penelitian dan Pembahasan}

1. Tata Pemerintahan Desa Yosorejo

Struktur pemerintahan di Kecamatan Petungkriyono dimulai dari entitas paling kecil yaitu RT, RW atau dusun, Kepala Desa, dan Camat. ${ }^{9}$ Setiap RT mempunyai seorang ketua RT yang dipilih oleh masyarakat yang tidak mendapatkan imbalan apa-apa baik dari masyarakat maupun pemerintah. Kepala RW atau Kepala Dusun $(\text { Pak Bawu })^{10}$ dipilih oleh masyarakat dengan pemilihan langsung dan mendapat gaji Rp500.000 per bulan, sedangkan kepala desa mendapatkan gaji sebesar Rp750.000 per bulan. Kepala dusun/RW membantu kepala desa dalam hal administrasi desa, seperti membuat kartu tanda penduduk (KTP), sedangkan ketua RT hanya bertugas mengkoordinasikan kerja bakti dan menyelesaikan konflik antar warga di tingkat pertama secara berjenjang.

Berkaitan dengan masalah kehidupan keagamaan, penduduk Desa Yosorejo mayoritas beragama Islam, sehingga Desa Yosorejo mempunyai tradisi keagaaman tersendiri. Terdapat beberapa orang ustadz yang dikirim secara bergilir selama tiga

8 Lihat motode penelitian Antropologi Hukum dalam Hilman Hadikusumah, Pengantar Antropologi Hukum, Bandung: PT. Citra Aditya Bakti, 2004, hlm. 8-17.

9 Sebagai contoh Dusun Sikucing, Desa Yosorejo yang terdiri dari 3 RT (RT 1, 2, dan 3).

10 Pak Bawu adalah nama panggilan informal untuk kepala dusun di Kecamatan Petungkriyono. 
bulan oleh pasantren di Pekalongan. Ustadz tersebut bekerja selama tiga hari di tiap-tiap dusun. Kemudian di setiap malam tertentu dalam seminggu diadakan 'wiritan' warga di setiap dusun yang dilakukan di rumah warga secara bergilir, sementara di malam jumat diadakan 'wiritan' untuk seluruh desa. Para ustadz ini nampak masih berusia muda, dan kegiatannya di Desa Yosorejo merupakan bagian dari pengabdian mereka dalam menuntut ilmu di pesantren. Desa Yosorejo terdiri dari 4 dusun (RW) dan 12 RT, yaitu dusun Dranan, Garung, Candi, dan Sikucing. Sedangkan jumlah Kepala Keluarga di Desa Yosorejo adalah sekitar 349 Kepala Keluarga dengan jumlah penduduk 1605 jiwa.

\begin{tabular}{|c|c|c|c|c|}
\hline \multicolumn{5}{|c}{ Desa-Desa di Kecamatan Petungkriyono } \\
\hline No. & Nama Desa & $\begin{array}{c}\text { Jumlah } \\
\text { Penduduk }\end{array}$ & Laki-Laki & Perempuan \\
\hline 1 & Simego & 1.811 & 928 & 883 \\
\hline 2 & Songgodadi & 1.118 & 571 & 547 \\
\hline 3 & Curugmuncar & 492 & 247 & 245 \\
\hline 4 & Gumelem ${ }^{11}$ & 808 & 408 & 400 \\
\hline 5 & Tiogohendro & 2.592 & 1.310 & 832 \\
\hline 6 & Yosorejo & 1.656 & 824 & 1.017 \\
\hline 7 & Tlogopakis & 2.128 & 1.111 & 440 \\
\hline 8 & Kasimpar & 878 & 438 & 6.328 \\
\hline 9 & Kayupuring & 1.371 & 687 & 6.542 \\
\hline Jumlah & & 12.852 & & 680 \\
\hline
\end{tabular}

Sumber: Data KUA Kecamatan Petungkriyono 2009.

11 Desa Gumelem merupakan desa yang paling makmur jika dibandingkan dengan desa-desa lain di Kecamatan Petungkriyono. Desa ini dikenal sebagi penghasil kentang yang dikirim sampai ke Jakarta. Hal ini juga didukung dengan angka paling banyak yang berqurban (28 orang) pada hari raya qurban tahun 2009. Data tersebut diperoleh dari Kantor Urusan Agama Petungkriyono 2010. 


\section{Hukum Dalam Masyarakat Sederhana}

Dalam rangka memberi definisi terhadap hukum, banyak ahli yang berupaya memberi pendapatnya, misalnya Simorangkir, yang melihat dari sudut pandang normatif dan yuridis formal, bahwa hukum adalah "aturan-aturan yang bersifat memaksa, yang menentukan tingkah laku manusia dalam suatu lingkungan masyarakat, yang dibuat oleh badan-badan resmi yang berwajib, dan pelanggaran terhadap aturan-aturan tadi akan diambil tindakan berupa hukuman tertentu". ${ }^{12}$ Penjelasan ini memberi pemahaman bahwa hukum hanya ada dalam masyarakat yang modern di mana sudah terdapat lembaga-lembaga pembuat aturan-aturan pengikat setiap warga negaranya dalam wilayah hukum tertentu, serta akan diberikan sanksi bagi si pelanggar.

Pada masyarakat sederhana, tentu definisi ini tidak dapat diterapkan, karena masyarakat ini tidak mempunyai lembaga pembuat hukum serta lembaga penegakannya. Penulis menganggap Desa Yosorejo mewakili masyarakat sederhana yang dapat dibedakan dengan masyarakat modern di perkotaan. Situasi ini tidak dapat ditafsirkan bahwa masyarakat sederhana tidak mempunyai hukum, karena masyarakat ini hidup dalam ketertiban dan kedamaian. Jika terdapat konflik, akan dengan mudah dapat diselesaikan. Karena itu ada upaya dari para antropolog hukum untuk melihat fenomena ini sebagai sebuah proses bekerja dan fungsi hukum dalam masyarakat secara keseluruhan. ${ }^{13}$ Inilah yang menghasilkan kesepakatan bahwa hukum adalah 'kontrol sosial'. Sehingga, hukum juga dipahami sebagai nilai-nilai budaya yang secara konkrit ada dalam norma-norma sosial yang selalu terumus dalam setiap bentuk kehidupan bersama dari manusia sebagai pedoman yang diajarkan kepada para warganya supaya dijadikan pedoman dalam berperilaku. ${ }^{14}$ Penjelasan ini paling tidak dapat memberikan dasar pemahaman dalam mencari hubungan antara hukum dan budaya.

Koentjoroningrat memberikan definisi hukum sebagai "suatu aktivitas dalam suatu kebudayaan yang memiliki fungsi pengawasan sosial."15 Istilah hukum tidak hanya dilihat secara normatif, tapi menjadi sebuah unsur yang terlibat langsung dalam tata kelola kehidupan suatu masyarakat. ${ }^{16}$ Jadi, hukum harus dikaitkan

12 Simorangkir JCT, Pelajaran Hukum Indonesia, Jakarta: Pradnya Paramita, 1986, hlm. 13.

13 Antropologi Hukum sebagai sebuah perspektif untuk melihat berbagai macam corak hukum yang lahir dan berkembang dari berbagai corak dan ragam kebudayaan. Mempelajari Antropologi Hukum berarti kita melihat sebuah realitas, kenyataan atas kehidupan hukum yang sesungguhnya berjalan di masyarakat. Lihat Fokky Fuad, "Antropologi Hukum, Sebuah Pengakuan atas Keberagaman Hukum", http://www.uai.ac.id/index.php/ in/hukum/91-antropologi-hukum-sebuah-pengakuan-atas-keberagaman-hukum, diakses 2 Maret 2010. Antropologi Hukum dapat pula berarti ilmu yang mempelajari perilaku manusia dalam kaitannya dengan aturan hukum. Lihat Hilman Hadikusumah, Op.cit., hlm. 8-9.

14 Lihat Ihromi (ed), Antropologi Hukum Indonesia, Jakarta: Yayasan Obor Indonesia, 1984, hlm. 2-3.

15 Lihat Koentjoroningrat, Pengantar Ilmu Antropologi, Jakarta: Aksara Baru, 1989, hlm. 7.

16 F. Von Benda-Beckman, "From the Law of Primitif Man to the Social Legal Study of Complex Societies", Makalah disampaikan pada Seminar Antropologi Hukum, Fakultas Hukum Universitas Indonesia, 1989, hlm. 26. 
dengan segenap unsur-unsur yang ada dalam masyarakat seperti ekonomi, politik, kekerabatan, agama, dan adat istiadat yang mempengaruhi baik secara langsung maupun tidak langsung terhadap proses hukum dalam masyarakat. Aturan-aturan yang hidup dalam masyarakat juga disebut hukum adat yang diperkenalkan pertama kali oleh Snouck Hurgronje, yang dikembangkan kemudian oleh Van Vollenhoven, yang memberi definisi hukum adat sebagai "keseluruhan tingkah laku positif yang di satu pihak mempunyai sanksi hukum, dan di pihak lain tidak dikodifikasikan."17 Aturan tersebut turun-temurun secara alami dari satu generasi ke generasi yang lain tanpa ada hambatan berarti. Sifat yang mengikat secara sosial begitu efektif dalam masyarakat terisolir seperti di Kecamatan Petungkriyono khususnya Desa Yosorejo. ${ }^{18}$

\section{Ragam Konflik dan Cara Penyelesaiannya}

Konflik adalah pertentangan atau perselisihan terhadap apa saja, baik antara dua pihak atau lebih, yang timbul dari kepentingan yang berbeda-beda. Pihak yang berkonflik bisa individu, kelompok, ataupun institusi. Pertentangan kepentingan itu timbul karena persaingan untuk menguasai suatu wilayah dan memanfaatkan sumber daya lainnya atau potensi-potensi kekuasaan, atau karena ketidaksepakatan ideologi tentang nilai-nilai dan norma-norma, sehingga konflik merupakan bagian yang tidak dapat dihindarkan dalam kehidupan sosial. Wujud konflik bisa bermacam-macam seperti pertentangan mulut, perkelahian, peradilan, revolusi, bahkan peperangan. ${ }^{19}$

Menurut Nader dan Todd, konflik atau sengketa dapat dibedakan menjadi 3 tahapan:

1. Pra-konflik, yaitu keadaan yang didasari rasa tidak puas seseorang atau kelompok;

2. Konflik, keadaan di mana para pihak menyadari atau mengetahui tentang adanya perasaan tidak puas tersebut; dan

3. Post-konflik, keadaan di mana konflik tersebut dinyatakan di muka umum atau dengan melibatkan pihak ketiga. ${ }^{20}$

Konflik atau sengketa dapat terjadi dalam situasi dan masyarakat apa saja, demikian juga dalam masyarakat Desa Yosorejo. Persoalan-persoalan dalam hubungan sosial tidak dapat dihindari, baik terkait dengan ekonomi, politik, rumah

17 Iman Sudiyat, Azas Azas Hukum Adat, Yogyakarta: Liberty, 1985, hlm. 5.

18 Untuk melihat perilaku umum orang Jawa, lihat Hilman Hadikusumah, Antropologi Hukum Indonesia, Bandung: PT. Alumni, 2006, hlm. 153-168.

19 Lihat Hunter dan Whitten, Encyclopedia of Anthropology, New York, Hagerstown, San Franscisco: Harper and Row Publisher, 1976, hlm. 88.

20 Laura Nader dan Harry F. Todd, The Disputing Process, Law In Ten Societies, New York: Colombia University Press, 1978, hlm. 34. 
tangga, dan sebagainya. Berdasarkan informasi dari beberapa tokoh masyarakat, adanya kepercayaan bahwa hidup harus 'nerimo' secara turun-temurun, menyebabkan penyelesaian konflik lebih bersifat internal daripada eksternal. Rasa malu akan konfliknya diketahui oleh orang luar masih sangat kental, sehingga sulit bagi mereka untuk mengungkapkan secara detail sebuah konflik yang terjadi. Dengan demikian, salah seorang Kepala Dusun di Desa Yosorejo menyatakan "tidak ada konflik berarti di desa ini, masalah umumnya diselesaikan secara kekeluargaan." ${ }^{21}$ Tarmanto, seorang polisi asli dari Yosorejo menyatakan jika ada perkelahian, biasanya selesai dengan sendirinya, salah satu pihak akan mengalah. Namun demikian penulis menemukan beberapa jenis konfilik yang terjadi di desa-desa di kecamatan Petungkriyono, antara lain:

\section{a. Konflik dengan Alam Sekitar}

Dari data rekapitulasi gangguan ketentraman dan ketertiban/kriminalitas di Kantor Kecamatan Petungkriyono, pada tahun 2009, dari 18 bentuk kejadian yang disebut dalam daftar, ${ }^{22}$ hanya terdapat 8 kasus banjir dan tanah longsor. Hal ini sering terjadi di musim hujan, di mana lereng-lereng gunung longsor dan menutupi jalan. Untuk mengatasi hal ini, pihak kecamatan selalu menyiapkan petugas siang dan malam yang berjaga di Kantor Kepala Desa atau kecamatan untuk selalu siap membersihkan jalan yang longsor. Hal ini menunjukkan konflik yang terjadi bukanlah konflik antar manusia tapi lebih kepada konflik antara manusia dengan alam. Selain itu, penyelesaiannya juga dikelola secara baik di tingkat desa, di mana petugas yang berjaga di kantor mengajak warga sekitar untuk membersihkan tanah-tanah longsor tersebut, ataupun bencana alam lainnya. Unsur kebersamaan dan gotong royong menjadi landasan perbuatan tersebut, karena tidak ada budget khusus untuk menangani konflik masyarakat Desa dengan alam sekitar.

\section{b. Konflik atau Sengketa Keluarga}

Berdasarkan data dari Kantor Urusan Agama (KUA) Kecamatan Petungkriyono, ${ }^{23}$ dapat dilihat bahwa pada tahun 2009, di Desa Yosorejo terdapat 2 kasus (satu talak, satu cerai) dari 9 kasus talak cerai di Kecamatan Petungkroyono. Berdasarkan informasi dari Pak Bawu di salah satu dusun di Desa Yosorejo, hal ini terjadi murni karena ketidakcocokan. Namun, berdasarkan data dari pihak KUA sebab terjadinya perselisihan dan perceraian semuanya adalah karena alasan 'meninggalkan suami atau isteri'. Berdasarkan pengamatan, terdapat beberapa orang dari Desa Yosorejo yang pergi merantau ke kota seperti Pekalongan, Semarang, Sumatera, bahkan

21 Wawancara dengan Bapak Solihin, Kepala Dusun Sikucing Desa Yosorejo, 20 Januari 2010.

22 Seperti pembunuhan, perjudian, perzinaan, pemerasan, aniaya berat, pemalsuan, pencurian berat, kenakalan remaja, pencurian dengan kekerasan (curas), pencurian motor (curanmor), narkotika, kecelakaan, bunuh diri, penculikan, penipuan, pengrusakan, kebakaran, dan lain-lain.

23 Data ini diperoleh dari Kepala Kantor Urusan Agama Islam Kecamatan Petungkriyono, Bapak Imron, S.Ag., 21 Januari 2010. 
Jakarta. Hal ini sangat berbeda dengan kecamatan lain di Pekalongan, yang mana hampir sepertiga suami atau istri meninggalkan keluarga dan anak untuk bekerja di Malaysia. ${ }^{24} \mathrm{Hal}$ tersebut menjadi salah satu dari penyebab perceraian di daerah ini. ${ }^{25}$

Dari 2 (dua) kasus perceraian di Desa Yosorejo, terindikasi bahwa satu kasus terjadi dalam usia perkawinan di bawah satu tahun, sedangkan satu kasus lagi dalam masa perkawinan 5-10 tahun. Para pihak adalah lulusan SD yang bekerja sebagai petani dan karyawan. ${ }^{26}$ Berdasarkan pemantauan penulis, sangat jarang masyarakat di Desa Yosorejo yang menjadi karyawan, besar kemungkinan karyawan di sini adalah pekerja yang sudah merantau keluar dari kecamatan tersebut. Pada umumnya, warga masyarakat melaksanakan perkawinan pada usia yang cukup muda, mempelai laki-laki pada umumnya berusia 19-25 tahun, sedangkan mempelai perempuan antara 16-19 tahun. Meskipun menurut data ini usia paling kecil perkawinan adalah usia 16 tahun, akan tetapi menurut Pak Roni, seorang staf Kantor Kecamatan Petungkriyono, terdapat indikasi bahwa usia mereka masih berada di bawah 16 tahun tetapi menulis di KTP 16 tahun atau lebih, sehingga mungkin saja ada usia yang di bawah 16 tahun yang juga melakukan perkawinan. ${ }^{27}$

Berdasarkan data dari Pengadilan Agama Kajen, ${ }^{28}$ merupakan pengadilan yang mewadahi yurisdiksi relatif untuk wilayah Kecamatan Petungkriyono, sebagai berikut:

\begin{tabular}{|c|c|c|}
\hline Perceraian & $\mathbf{2 0 0 8}$ & $\mathbf{2 0 0 9}$ \\
\hline Cerai Talak & 254 & 313 \\
\hline Cerai Gugat & 727 & 823 \\
\hline Jumlah Kasus & $\mathbf{9 8 1}$ & $\mathbf{1 1 3 6}$ \\
\hline
\end{tabular}

24 Hasil wawancara dengan Panitera Muda Bagian Hukum, Pengadilan Agama Pekalongan, Jawa Tengah, 26 Januari 2010.

25 Kasus-kasus lain tergolong sangat sedikit, seperti 1 kasus asal usul anak, 1 kasus dispensasi kawin, 4 kasus wali Adhal, dan 4 kasus kewarisan di tahun 2007, begitu juga di tahun 2008 dan 2009, tidak ada angka kenaikan kasus-kasus lain selain perceraian.

26 Data dari Kantor Urusan Agama Petungkriyono, 31 Desember 2009.

27 Wawancara dengan Bapak Roni, staf bagian pemerintahan Kecamatan Petungkroyono.

28 Kabupaten Kajen merupakan pemekaran dari Kabupaten Pekalongan. Karena merupakan suatu kabupaten baru, belum semua infrastruktur kabupaten tersedia, bahkan ada sebagian kantor yang masih tunduk di bawah Kabupaten Pekalongan, seperti Pengadilan Negeri Pekalongan. 
Sebagai perbandingan, di kecamatan tetangga lain seperti data dari Pengadilan Agama Pekalongan tentang laporan perkara yang diterima tentang perceraian sebagai berikut:

\begin{tabular}{|c|c|c|c|}
\hline Perceraian & $\mathbf{2 0 0 7}$ & $\mathbf{2 0 0 8}$ & $\mathbf{2 0 0 9}$ \\
\hline Cerai Talak & 99 & 97 & 84 \\
\hline Cerai Gugat & 180 & 264 & 195 \\
\hline Jumlah Kasus & $\mathbf{2 7 9}$ & $\mathbf{3 6}$ & $\mathbf{2 7 9}$ \\
\hline
\end{tabular}

Jumlah kasus talak cerai di Kecamatan Petungkriyono tentu tidak berbanding lurus dengan besarnya angka di Pengadilan Agama tersebut. Ini berarti kasus perceraian yang terdaftar di Pengadilan Agama Kajen adalah kebanyakan dari kecamatan selain Petungkriyono. Kondisi ini memperjelas keunikan Petungkriyono dari kecamatankecamatan yang lain. Kondisi ini mungkin dipengaruhi oleh kondisi sosiologis masyarakat yang masih memegang teguh pada nilai-nilai kebersamaan, ketenangan, dan penyelesaian konflik berbasis kearifan lokal.

Hal ini juga didukung oleh masih jauhnya akses perubahan gaya hidup dari kota. Bagimanapun, kehidupan kota yang lebih hedonis dan materialis akan memberi perubahan cukup besar terhadap pola tingkah laku suatu masyarakat. Oleh karena itu, kondisi ini sangat mungkin berubah 10-20 tahun mendatang ketika akses orang luar semakin besar dan mudah di Petungkriyono. Secara umum, kasus-kasus konflik keluarga dapat terselesaikan dengan baik di tingkat kepala dusun.

\section{c. Konflik Politik}

Di Dusun Sikucing, Desa Yosorejo terjadi konflik antara kepala dusun dengan masyarakat. Masyarakat merasa tidak nyaman dengan kepemimpinan Kepala Dusun, sehingga melaporkannya kepada Kepala Desa dan mengusulkan pemilihan Kepala Dusun baru. Setelah terpilih Kepala Dusun baru secara aklamasi, Kepala Dusun lama masih merasa dirinya sebagai pemimpin karena kepala dusun yang baru belum dilantik. ${ }^{29}$ Masyarakat Desa Yosorejo tidak begitu suka berkonflik, akan tetapi jika ada sesuatu yang tidak sesuai dengan kehendak mereka, masyarakat tidak segan untuk mengadu. Kepala Desa secara tersirat menjelaskan bahwa masyarakat tidak suka melihat pemimpin yang hanya pandai berbicara, akan tetapi kurang

29 Kepala Dusun lama merasa ada oknum warga yang melapor ke Kepala Desa tentang kekuranganya, akan tetapi setelah Kepala Desa meminta warga untuk mencari bukti-bukti, tidak ditemukan bukti-bukti tersebut. Namun demikian keinginan masyarakat sangat kuat, sehingga beliau menyerahkan jabatan Kepada Dusun kepada Bapak Kepala Desa. (Data dari hasil wawancara pada 16 Januari 2010) 
dalam melakukan aksinya, seperti jika ada acara kerja bakti, hanya masyarakat yang diminta berpartisipasi, sedangkan beliau selaku pemimpin sendiri tidak ikut serta. Pola penyelesaian konflik politik dengan melapor ke pejabat lebih tinggi merupakan model penyelesaian khas masyarakat Desa Yosorejo. Mereka akan melakukan tindakan-tindakan yang terus berjenjang untuk mencapai keinginan penyelesaiannya. Di sini tidak terlihat ada budaya kekerasan dalam penyelesaian konflik, melainkan lebih mengutamakan jalur struktural dan damai.

\section{d. Konflik Pertanahan}

Selama tiga tahun terakhir, tidak ada kasus apapun yang berkaitan dengan konflik pertanahan, kecuali satu kasus konflik batas tanah di Dusun Dranan yang berhasil diselesaikan oleh Kepala Desa. Biasanya, konflik antar warga diselesaikan di tingkat RT, kemudian jika tidak selesai dibawa ke Pak Bawu, jika tidak selesai juga maka permasalahan akan dibawa ke Kepala Desa. Selanjutnya, jika tetap tidak selesai, biasanya Kepala Desa akan menyerahkan kasus tersebut ke pihak kepolisian. Menurut catatan, hanya ada satu kasus yang sampai dilaporkan ke kepolisian, yaitu kasus pencurian Tank Penyemprot tanaman (akhir 2007) di gubuk dekat lahan warga. Pencurinya adalah orang pendatang, akan tetapi Kepala Desa tidak mengetahui kelanjutan dari kasus tersebut setelah ditangani oleh pihak kepolisian.

Pertanahan menjadi potensi konflik ke depan jika tidak segera ditanggulangi. Selain status kepemilikan tanah warga yang belum jelas, konflik dapat terjadi karena warga harus tetap membayar pajak. Kepala Dusun Rowo, Telago Pakis mengungkapkan bahwa persoalan pertanahan di sini yang sudah diukur oleh Badan Pertanahan Nasional (BPN) untuk dibuat sertifikat, akan tetapi sampai sekarang tidak kunjung kabarnya. Padahal, warga sudah membayar ongkos pengukuran. Beliau menunjukan Surat Pemberitahuan Pajak Terhutang (SPPT) dari kantor pajak sebagai bukti kepemilikan tanah. Tentu ini sangat memprihatinkan, di mana beliau tetap harus membayar pajak meskipun tanpa surat kepemilikan tanah.

Konflik pertanahan bisa juga terjadi disebabkan karena masuknya perusahaan yang membeli tanah warga dengan harga murah seperti PT Medan Jaya pada tahun 1995 yang hendak membangun pabrik di Desa Igir Gede untuk penanaman dan pengolahan jamur. Namun, pada saat krisis moneter sekitar tahun 1998, perusahaan yang dimaksud mengalami kebangkrutan. Padahal, PT Medan Jaya sudah terlanjur membeli tanah seluas $12 \mathrm{Ha}$ (per meter dihargai Rp1000) dan membangun pondasi untuk pabrik. Ketidakjelasan rencana pembangunan pabrik mendorong warga untuk membeli kembali lahan pabrik. Ternyata pada akhirnya diketahui tanah itu sudah berpindah tangan ke pemilik baru yaitu warga Karangkobar, Banjarnegara dengan harga per meter Rp3000. Hingga kini sebagian lahan terbengkalai karena tidak ada yang mengolah dan sebagian besar lahan sudah diratakan/dipadatkan sehingga lapisan tanah yang gembur telah hilang. 
Cara masyarakat desa menyelesaikan konflik secara berjenjang ini dapat digambarkan dalam bagan sebagai berikut:

\section{Bagan Penyelesaian Konflik di Desa Yosorejo}

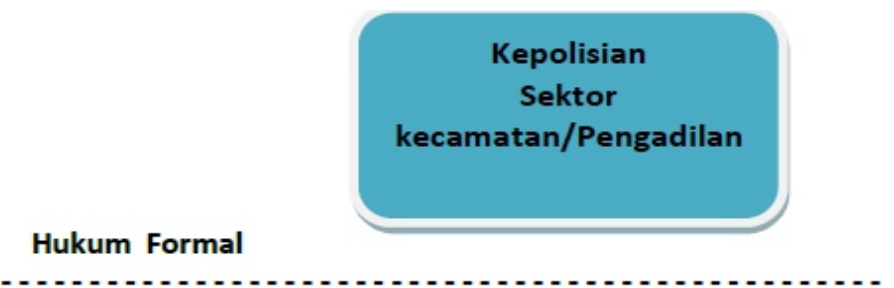

\section{Hukum Informal}

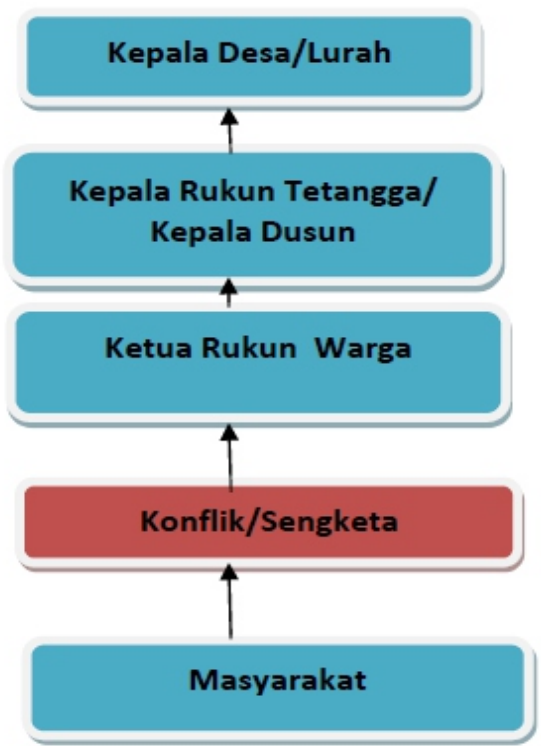

Telihat tahapan yang panjang dalam penyelesaian secara informal namun masyarakat lebih memilih hal ini. Hal ini juga mungkin dipengaruhi oleh kepercayaan masyarakat justru rendah terhadap penyelesaian konflik secara formal.

Seorang polisi di kepolisian Sektor Petungkriyono, Tarmanto, yang merupakan orang asli dari Dusun Dranan, menjelaskan bahwa hanya terdapat 12 anggota kepolisian termasuk Kepala Polsek, lalu selama bertugas hampir tidak ada kasus yang ditangani, kecuali di tahun 2008 terdapat kasus pencurian tank semprot di 
Desa Gumelem. Sedangkan kasus-kasus lain biasanya dapat diselesaikan secara kekeluargaan di tingkat dusun atau desa. ${ }^{30}$ Ketiadaan kasus-kasus konflik dan sengketa di kepolisian sebagai aparat penegak hukum formal dapat disebabkan oleh beberapa faktor:

1. Kesamaan profesi sebagai petani dan peternak sehingga mempunyai kesamaan waktu istirahat dan kegiatan lainnya;

2. Kesamaan suku, tidak ada satupun pendatang yang tinggal di desa tersebut sehingga perkembangannya berjalan searah;

3. Tidak ada diskriminasi gender, laki-laki dan perempuan sama-sama bekerja, di ladang atau di kebun kebun karet;

4. Budaya sungkan dan rasa malu masih sangat tinggi;

5. Adanya kontrak sosial dan kontrol sosial yang tinggi dalam setiap tata kehidupan masyarakat;

6. Adanya polisi desa di setiap desa yang berada di bawah koordinasi kepala desa, bukan dari kepolisian;

7. Kondisi alamnya yang masih natural, belum terjamah;

8. Kepercayaan bahwa mereka tidak boleh menjual makanan pokok seperti beras dan jagung, sehingga kebutuhan pokok mereka dalam batas tertentu sudah terjamin;

9. Hampir semua keluarga mempunyai ternak sapi sampai 4 (empat) ekor sebagai investasi untuk membeli motor, rumah, dan sebagainya; dan

10.Perkawinan sangat mudah, dengan rentang mahar Rp30.000 sampai dengan Rp1.300.000 rupiah $^{31}$ mereka sudah dapat menikah, dan umumnya masyarakat desa menikah pada usia muda.

Selain 10 hal yang telah dikemukakan di atas, desa-desa di kecamatan Petungkriyono juga masih melaksanakan tradisi dan kearifan lokal yang mengikat kebersamaan mereka yang juga merupakan simbol-simbol penyelesaian konflik.

\section{Simbol-Simbol Penyelesaian Konflik sebagai Kearifan Lokal}

\section{a. Selametan}

'Selametan' merupakan hal yang menjadi kebiasaan dalam masyarakat Desa di Kecamatan Petungkriyono dalam rangka membina keharmonisan hubungan dengan arwah leluhur dan Tuhan. Kegiatan dilakukan antara lain dengan membakar kemenyan, menghidangkan makanan dan minuman tertentu, serta pembacaan doa di hadapan beberapa orang yang khusus diundang untuk acara tersebut. Selametan biasanya dilakukan di dalam rumah. Sebagai contoh, di Desa Tlogopakis diadakan

30 Wawancara dengan Tarmanto pada 19 Januari 2010 di Kantor Polisi Sektor Petungkriyono.

31 Menurut Bapak Kepala Kantor Urusan Agama Petungkriyono, pada 21 Januari 2010 terjadi pesta perkawinan termahal di Petungkriyono, di mana sebelumnya belum pernah ada jumlah mahar melebihi Rp1,300,000,-. 
selametan 40 hari setelah perluasan rumah pak lurah. ${ }^{32}$ Tiap bulan Syuro, masyarakat Desa juga mengadakan selametan dengan menggunakan bubur merah dan bubur putih.

\section{b. Sesajen}

Sesajen merupakan sebuah kebiasaan yang turun temurun untuk menghormati ruh-ruh leluhur dan makhluk halus lainnya yang dipercayai sering berkunjung dalam waktu dan tempat tertentu, seperti setiap Kamis malam dan setiap malam Jumat Kliwon. Sesajen dapat berbentuk makanan atau minuman seperti air kopi atau teh, air putih, bungkusan nasi, ketela bakar, dan bunga mawar. Semua barang itu diletakkan dalam 'penamban', sebuah wadah yang terbuat dari seng yang biasa dipakai untuk menghidangkan air kepada tamu. Masyarakat percaya bahwa dengan menghormati leluhur dan makhluk halus yang datang akan berdampak positif dalam kehidupan mereka. Sebaliknya, jika tidak memberi sesajen, para leluhur dan makhluk halus akan murka dan berakibat bencana dalam berbagai bentuk.

Di Desa Wonodadi, ${ }^{33}$ sesajen diletakkan di turbin listrik yang ada di dekat jembatan. Sesajen diberikan oleh masyarakat secara bergiliran pada setiap Kamis malam. Sesajen diantar pada sore hari di Hari Kamis. Di dusun Telago Hendro, terdapat sebuah danau di mana setiap dua tahun sekali masyarakat membenamkan kepala binatang sebagai suatu kepercayaan yang turun temurun. Sesajen juga dapat berbentuk pengadaan aktivitas tertentu dalam waktu tertentu. Hal ini dapat dilihat di Desa Simego yang selalu mengadakan ronggeng atau tayuban setiap bulan legen (Dzulkaidah). Jika tidak dilakukan, diyakini akan terjadi bencana seperti adanya orang gila atau paceklik dan gagal panen.

\section{c. Tahlilan/Yasinan}

Tahlilan atau yasinan dilakukan sebagai sarana untuk berkumpul antara masyarakat setelah sehari-hari selama seminggu bekerja di kebun atau di hutan. Keyakinan agama dan kebutuhan sosial sebagai tempat kumpul mingguan menjadikan tahlilan terus bertahan sebagai institusi sosial tempat berkumpul dan saling tukar-menukar informasi. Pada sebagian tempat, hanya praktik tahlilan semata yang dilakukan, seperti di dusun Sikucing Desa Yosorejo. Sedangkan di desa lain dilakukan yasinan dan tahlilan. Selesai ritual bacaan, biasanya tersedia makanan dan minuman dari tuan rumah yang dipilih secara bergilir setiap minggu. Tahlilan ini biasanya dipimpin oleh ustadz-ustadz yang dikirim secara bergilir oleh pesantren-pesantren di daerah Pekalongan.

\footnotetext{
32 Ilustrasi kegiatan selametan 40 hari pelebaran rumah Kepala Desa di Desa Tlogopakis pada 17 Januari 2010 : 10 orang 'tetua' (tokoh) Desa duduk melingkari hidangan makanan dan pembakaran kemenyan. Tetua membaca mantera dalam bahasa Jawa, Al-fatihah, shalawat, dan doa.

33 Laporan Sehat Ihsan Shadiqin, Op.cit.
} 


\section{d. Penghormatan terhadap Tempat dan Situs-Situs Kuno}

Di Igir Gedhe, Simego, terdapat suatu 'Kolam Larangan'. Tempat ini terkenal angker. Menurut cerita warga, pernah terjadi kejadian beberapa anak SMA yang sedang berkemah di dekat sana mengalami kesurupan karena melanggar larangan. Larangan tersebut antara lain adalah buang air kecil atau meludah di kolam tersebut. Selain itu, di Desa Songgodadi juga terdapat Situs Nogokertolo atau Situs Linggoyoni I, atau yang lebih dikenal dengan Nogokortoloi (Abad IV-XII M), di mana setiap tahun diadakan selametan nasi hitam dan ayam putih. Desa ini dianggap sebagai tempat yang paling aman, karena dilindungi oleh 3 Mbah Kyai, yaitu Kyai Serak, Maja Sutra, Pagang, yang kuburannya ada di desa tersebut. Di desa tersebut terdapat motto: "walaupun tak punya yang penting tak ganggu teman". Sekretaris Kecamatan, Samsudit, memperingatkan Penulis agar menjaga tradisi-tradisi pantangan dalam mitos-mitos masyarakat di sini. Beliau menyatakan "masyarakat di sini (Petungkriyono) sangat tentram dan kondusif, tidak terlalu mengurusi politik, petani dan peternak, ilegal loging tidak ada, yang perlu cuma infrastruktur".

\section{e. Jimat dan Supra Natural}

Jimat merupakan sebuah benda yang diyakini dapat menolak bahaya ataupun mendatangkan keberuntungan. Setiap bayi yang lahir dan ibu yang melahirkan diberikan sebuah jimat oleh Bu Dukun. Jimatnya harus dipakai sampai bayi sudah besar dan bisa mandiri. Bermacam-macam cara pakai jimat yang diberikan, ada yang dipakai di peniti di baju, dikalungkan, dan ada juga yang diikatkan di selendang yang sering dipakai untuk menggendong bayi. Masyarakat tidak mengetahui isi jimat secara persis, tapi mereka menerimanya secara turun temurun. Jimat itu diberikan dan dipercayai bisa menolak mara bahaya bagi si bayi dan ibu yang baru saja melahirkan. ${ }^{34}$

Di Desa Songgowedi, apabila ada orang yang kesurupan, akan dibawa ke pak lebai. Bila ada yang akan melangsungkan hajatan, menikah, atau mendirikan rumah, maka masyarakat desa akan datang menghadap ke pak lebai untuk meminta wejangan hari baik. Harapannya, agar tidak akan terjadi sesuatu yang akan jadi petaka di masa depan. Ada juga yang datang untuk meminta petuah agar lekas mendapat jodoh dan persoalan-persoalan kehidupan lainnya. ${ }^{35}$ Pengkultusan ini akan memudahkan masyarakat dalam menyelesaikan konflik-konflik sosial.

\section{f. Penghormatan terhadap Hari-Hari Tertentu}

Ibu Siti dari Desa Karanggongdang menjelaskan bahwa di setiap Jumat Kliwon, Jumat Wage, dan Selasa Kliwon, para petani tidak pergi ke sawah karena mereka percaya di hari-hari itu para leluhur datang ke dusun untuk menyambangi keturunannya('niliki anak putu'). Sehingga, tabu bagi mereka untuk meninggalkan

\footnotetext{
34 Laporan harian Retno Ariwijayanti, hlm. 4.

35 Ibid.
} 
rumah dan menggarap sawah. Mereka tidak ingin meninggalkan rumah saat leluhur datang berkunjung. Ketika Penulis hendak menuju air terjun Curug Muncar bertepatan dengan Jumat Kliwon, di mana dipercaya semua arwah leluhur turun ke bumi, pak Bawu melarang Penulis menuju ke sana. Menurut cerita, seorang siswa SMP meninggal setelah 'kemasukan' karena mengambil setangkai bunga dari Curug. ${ }^{36}$ Selain itu, dalam menentukan hari baik untuk perkawinan, mereka menggunakan hitungan sendiri yang biasanya dengan meminta nasehat dari orang yang dipercaya di sana. ${ }^{37}$

\section{Hegemoni Hukum Formal dan Kontrol Sosial}

Hal yang menarik dalam masyarakat Desa Yosorejo adalah masih kuatnya kontrol sosial dalam tata kehidupan masyarakat. Hal ini yang meminimalisasi keinginan untuk melakukan kejahatan terhadap yang lain. Kehidupan pedesaan yang saling membutuhkan membuat masyarakat desa seolah-olah bersatu dalam budaya, kepercayaan, dan kepentingan. Hal ini didukung oleh faktor-faktor, seperti masih belum banyaknya masyarakat luar yang masuk ke wilayah ini, sehingga homogenitas masyarakat masih terjaga. Susahnya akses transportasi, menyebabkan banyak orang luar enggan untuk masuk ke wilayah ini.

Kondisi tata kelola desa yang demokratis dan mengutamakan kepentingan bersama mendorong kepada bentuk penyelesaian konflik yang alami di tingkat paling rendah dari RT masing-masing. Tingkat kepercayaan terhadap pemimpin desa yang tinggi memudahkan penyelesaian persoalan tanpa harus membawanya ke tingkat yang lebih tinggi. Ketika kontrol sosial masih kuat, fungsi hukum formal dengan institusinya tidak begitu bermakna. Fungsi lembaga penegak hukum seperti polisi hanya bersifat formalitas semata, terlebih lagi lembaga pengadilan, kejaksaan, dan sebagainya. Hukum kebiasaan yang merupakan hukum yang hidup dalam masyarakat dirasa jauh lebih efektif dalam penyelesaian konflik dalam masyarakat ini.

Selain itu, sistem di Pengadilan Kabupaten Kajen dan Pekalongan masih sangat memprihatinkan. Budaya hukum yang formalis sangat terasa. Akses terhadap informasi pengadilan begitu sulit untuk didapat. Meskipun sudah tersedia mesin informasi di lobi Kantor Pengadilan, akan tetapi ternyata pada kenyataannya belum berfungsi. Berdasarkan hasil pertemuan dengan Ketua Pengadilan Negeri

36 Wawancara dengan Bapak Mertua Pak Bawu Gunung Cilik, Desa Songgodadi pada 22 Januari 2010.

37 Perkawinan tidak boleh hitungannya lebih dari 30, akan lebih baik apabila jumlahnya 27. Jadi yang dimaksud adalah setiap pasangan yang akan menikah dihitung weton-nya lalu dijumlahkan. Misalnya, si gadis (calon mempelai wanita) lahir pada hari kamis kliwon, maka berarti Kamis $(8)+$ Kliwon $(8)=16$, sementara si pemuda (calon mempelai pria) lahir pada selasa (3) + wage (4), berarti jumlahnya 7 , lalu $16+7=23$, maka mereka boleh menikah. Senin: 4, Pon: 7, Selasa: 3, Wage: 4, Rabu: 7, Kliwon: 8, Kamis: 8, Pahing: 9, Jumat: 6, Legi: 5, Sabtu: 9. Wawancara dengan Pak Bawu Sikucing, 23 Januari 2010. 
Pekalongan, Ketua Pengadilan Agama Pekalongan, Kajen, dan Kejaksaan Pekalongan, dapat dipahami tentang budaya hukum yang masih jauh dari budaya hukum masyarakat. Hukum adalah untuk formalitas, bukan hukum untuk keadilan, apalagi untuk masyarakat. Ketua Pengadilan Negeri Pekalongan menyatakan bahwa "Saya bukan orang sini, jadi tidak tau apa-apa. Saya sebelumnya bertugas di Jakarta Selatan, saya baru enam bulan di sini, jadi tidak mengerti tentang kondisi hukum di sini...". ${ }^{38}$ Pola ketidaktahuan dan (mungkin) rasa tidak ingin tahu ini menjadi salah satu faktor penyebab Pengadilan semakin jauh dengan rasa keadilan masyarakat. Pengadilan seolah-olah terpisah dari sosiologis masyarakat dalam yurisdiksinya. Pengadilan seperti 'fatamorgana keadilan'. Maka, beruntunglah masyarakat Petungkroyono yang karena 'ditakdirkan' secara geografis terisolir sehingga lebih mengutamakan penyelesaian perkara di luar peradilan. Fenomena gunung es ini terjadi hampir di seluruh wilayah Indonesia, sebagai warisan dari sistem dan budaya hukum penjajah Belanda. ${ }^{39}$

Pemaknaan hukum oleh masyarakat ini mengisyarakatkan sebuah kondisi di mana sistem hukum impor yang selama ini kita gunakan tidak berfungsi dalam masyarakat yang sudah secara kuat memiliki nilai sendiri. Sistem hukum yang hidup dalam masyarakat Petungkriyono dapat dijadikan sebagai alternatif sistem hukum di Indonesia. Tentu hal ini memerlukan para ahli untuk mendesain ulang sistem hukum Indonesia yang lebih adil dan beradab. Menurut Satjipto Rahardjo, dengan kuatnya arus pemikiran 'positivis normatif' yang mendominasi alam pemikiran kaum intelektual dan arsitek hukum di tanah air. Sudah sepatutnya kita melihat sisisisi lain dari hukum untuk dapat menyembuhkan 'penyakit-penyakit hukum' yang tumbuh berkembang di Indonesia. ${ }^{40}$

Pendekatan tatanan hukum di sini adalah menyalahi pendekatan dominan yang mengedepankan penyelesaian kasus secara formal yuridis. Padahal, banyak kekurangan yang diakibatkan oleh sistem peradilan dan keadilan kita, seperti misalnya lamanya proses dan biaya perkara, serta jauh dari rasa keadilan masyarakat. Satjipto Rahardjo menyatakan, "tidak jarang hukum dipakai sebagai instrumen kekuasaan, padahal hukum secara historis bernuansa membela yang lemah dan terpinggirkan". ${ }^{41}$

Perebutan penguasaan sumber daya alam akan menjadi hal yang sensitif di masa yang akan datang saat pihak investor mulai mengelola beberapa sumber daya

38 Wawancara dengan Bapak Ketua Pengadilan Negeri Pekalongan pada hari Senin, 26 Januari 2010.

39 Penjelasan lebih lanjut lihat MY Aiyub Kadir, "The Application of the Law of Self-Determination in Postcolonial Context: A Guideline", East Asia Journal and International Law, Vol 8, Issue 1, 2016; dan MY Aiyub Kadir, "Revisiting Self-determination Conflict Settlements in Indonesia Context", Indonesian Law Review, Volume 5, Issue 2, 2015.

40 Lihat Satjipto Rahardjo, Sisi Sisi Lain dari Hukum di Indonesia, Jakarta: Penerbit Kompas, 2006, hlm. 10-11.

41 Ibid., hlm. xiv. 
alam di daerah tersebut. Pihak masyarakat tradisional mempertahankan penguasaan sumber daya alamnya dengan alasan konsumtif, sementara pihak luar pengusaha (perusahaan) berpegang kepada aturan formal untuk maraup kepentingan bisnis. Dari kondisi ini, akan terus berkembang menjadi suatu konflik terbuka dalam memperebutkan sumber daya alam yang semakin terbatas. Konflik yang terjadi, apabila tidak dapat diselesaikan dengan pranata penyelesaian konflik yang ada, akan dapat merusak struktur pranata sosial masyarakat tersebut. Sebagaimana masyarakat Jawa pada umumnya, pemaknaan terhadap konflik sangat tertutup. Konflik lebih diutamakan disimpan di dalam hati daripada diungkapkan kepada pihak luar. Ada beberapa hal yang menarik untuk dicermati dalam pola masyarakat Petungkriyono mengelola konflik.

\section{Penutup}

Penyelesaian konflik berbasis desa di masyarakat Desa Yosorejo Kecamatan Petungkriyono masih berlandaskan kepada penyelesaian di luar pengadilan, dengan mempercayai pimpinan desa sebagai fasilitator dalam forum penyelesaian konflik. Masing-masing pihak tunduk dan patuh atas segala keputusan pemimpin tersebut. Semua konflik dan sengketa dapat diselesaikan secara bijaksana tanpa harus berproses ke sistem hukum formal nasional. Kondisi geografis yang menyebabkan sulitnya komunikasi dan transportasi, rendahnya tingkat pendidikan, kepercayaan terhadap pemimpin desa, dan sifat mengalah 'nerimo' adalah nilainilai penunjang bertahannya pola penyelesaian sengketa berbasis desa ini.

Hukum formal negara tidak begitu berarti bagi masyarakat sederhana yang kehidupannya masih bergantung pada alam. Hukum yang hidup dalam masyarakat (living law) jauh lebih efektif dalam penyelesaian konflik di daerah pedalaman dibandingkan dengan hukum formal yang jauh dari rasa keadilan masyarakat. Sampai saat ini perkembangan sistem hukum Indonesia masih dipengaruhi oleh sistem hukum warisan penjajah Belanda yang lebih menekankan kepada hak-hak individualis, yang lambat laun mereduksi nilai-nilai sosial dalam masyarakat Indonesia. Keberhasilan masyarakat Desa Yosorejo meredam dan meminimalisasi konflik dapat menjadi acuan bagi penegak hukum nasional untuk menganalisa kembali sistem hukum nasional yang sudah terlalu jauh dari norma dan nilai-nilai yang hidup dalam masyarakat Indonesia.

\section{Daftar Pustaka}

\section{Buku}

Badan Perencanaan Pembangunan Daerah dan Badan Pusat Statistik Kabupaten Pekalongan, Kecamatan Petungkriyono dalam Angka 2008, Bappeda dan BPS Pekalongan, Juni 2009. 
Hilman Hadikusumah, Antropologi Hukum Indonesia, PT. Alumni, Bandung, 2006.

Bandung, 2004. , Pengantar Antropologi Hukum, PT. Citra Aditya Bakti,

Hunter dan Whitten, Encyclopedia of Anthropology, Harper and Row Publisher, New York, Hagerstown, San Franscisco, 1976.

Ihromi (ed), Antropologi Hukum Indonesia, Yayasan Obor Indonesia, Jakarta, 1984.

Iman Sudiyat, Asas-Asas Hukum Adat, Liberty, Yogyakarta, 1985.

Koentjoroningrat, Pengantar Ilmu Antropologi, Aksara Baru, Jakarta, 1989.

Nader, Laura dan Harry F. Todd, the Disputing Process, Law In Ten Societies, New York: Colombia University Press, 1978.

Satjipto Rahardjo, Sisi Sisi Lain Dari Hukum Di Indonesia, Penerbit Kompas, Jakarta, 2006.

Simorangkir JCT, Pelajaran Hukum Indonesia, Pradnya Paramita, Jakarta, 1986.

Soerjono Soekanto, Antropologi Hukum, Materi Pengembangan Hukum Adat, CV.

Rajawali, Jakarta, 1998.

\section{Dokumen Lain}

F. Von Benda-Beckman, "From the Law of Primitif Man to the Social Legal Study of Complex Societies", Makalah disampaikan pada Seminar Antropologi Hukum, Fakultas Hukum Universitas Indonesia, 1989.

MY Aiyub Kadir, "Revisiting Self-determination Conflict Settlements in Indonesia Context", Indonesian Law Review, Volume 5, Issue 2, 2015.

"The Application of the Law of Self-Determination in Postcolonial

Context: A Guideline", East Asia Journal and International Law, Vol 8, Issue 1, 2016.

Fokky Fuad, "Antropologi Hukum, Sebuah Pengakuan atas Keberagaman Hukum",

http://www.uai.ac.id/index.php/in/hukum/91-antropologi-hukum-sebuahpengakuan-atas-keberagaman-hukum, diakses 2 Maret 2011.

Laporan Harian Retno Ariwijayanti.

Laporan Sehat Ihsan Shadiqin di Desa Wonodadi.

Wawancara dengan Bapak Mertua Pak Bawu Gunung Cilik, Desa Songgodadi, 22 Januari 2010.

Wawancara dengan Bapak Roni, staf Bagian Pemerintahan Kecamatan Petungkroyono.

Wawancara dengan Bapak Solihin, Kepala Dusun Sikucing Desa Yosorejo, 20 Januari 2010.

Wawancara dengan Bapak Warnoto pada 16 Januari 2010 di Dusun Sikucing.

Wawancara dengan Kepala Kantor Urusan Agama Islam Kecamatan Petungkriyono, Bapak Imron, S.Ag., 21 Januari 2010.

Wawancara dengan Kepala Kantor Urusan Agama Petungkriyono, 21 Januari 2010. 
Wawancara dengan Ketua Pengadilan Negeri Pekalongan, 26 Januari 2010.

Wawancara dengan Pak Bawu Sikucing, 23 Januari 2010

Wawancara dengan Pak Ribut.

Wawancara dengan Panitera Muda Bagian Hukum, Pengadilan Agama Pekalongan, Jawa Tengah, 26 Januari 2010.

Wawancara dengan Tarmanto, 19 Januari 2010, di Kantor Polisi Sektor Petungkriyono.

Kantor Urusan Agama Kecamatan Petungkriyono, 2009, Laporan Tahunan, 31 Desember 2009.

Pengadilan Agama Pekalongan, Laporan Pengadilan Agama Pekalongan 2008 dan 2009. 